\title{
ONE-DIMENSIONAL POLLUTANT TRANSPORT MODELLING OF CADMIUM (Cd), CHROMIUM (Cr) AND LEAD (Pb) IN SAGULING RESERVOIR
}

\author{
Wiguna Sudiartha Gede Adi ${ }^{1 *}$, Oginawati Katharina ${ }^{1}$, Sofyan Asep ${ }^{1}$, Ardiwinata ${ }^{2}$, Kurnia Asep $^{2}$, Sukarjo ${ }^{2}$, \\ Handayani $\mathrm{Cici}^{2}$, Sulaeman ${ }^{2}$ \\ ${ }^{1}$ Environmental Engineering Master Programme, Faculty of Civil and Environmental Engineering, Bandung Institute of \\ Technology, Indonesia \\ ${ }^{2}$ Environmental and Agricultural Research Laboratory, Jakenan-Pati, Indonesia
}

\begin{abstract}
The existing conditions of the Saguling Reservoir are reported to have suffered severe heavy metal pollution due to the presence of wastewater inputs from various types of industries flowing into Citarum River and then accumulating in the Saguling Reservoir. From the results of calibration tests of heavy metal models on water using the Root Mean Square Error (RMSE) analysis and Relative Error (RE) analysis, obtained dispersion coefficients on Cadmium, Chromium, and Lead metals sequentially $1 \mathrm{~m}^{2} /$ second (with RMSE 0,00515 and $34 \%$ relative error); $1 \mathrm{~m}^{2} /$ second (with RMSE 0.00595 and relative error $26 \%$ ); and $2.5 \mathrm{~m}^{2} /$ second (with RMSE 0.028205 and relative error $41.25 \%$ ) which shows that the model has good capability to simulate the concentration of heavy metals approaching the actual data both in the dry and wet seasons. From the results of the verification test models of concentration of cadmium, lead and chromium in sediments using the Root Mean Square Error (RMSE) analysis and Relative Error (RE) analysis, obtained sequentially 18.53 and $77 \%$; 10.43 and $47.15 \% ; 2.789$ and $33 \%$. Error values in sediment concentrations are quite large because of the difficulty of making assumptions that are close to natural conditions. Keywords : finite difference, heavy metals, reservoir, WASP
\end{abstract}

\section{Introduction}

The existing condition of the Saguling Reservoir has suffered severe heavy metal pollution due to the presence of wastewater inputs from various types of industries entering through the Citarum River and then accumulating in the Saguling Reservoir. According to West Java BPLHD there were approximately 542 industries that strays along the bank of Citarum River which dispose its waste along the river flow and then discharged into Saguling Reservoir. These industries are dominated by the textile industry which is about $73 \%$ of the total type of industries. Based on Citarum River water quality data collected at Nanjung Station in 2013 (Input of Saguling Reservoir) some heavy metals were found with a concentration of Cadmium $(\mathrm{Cd})$ of $0.05 \mathrm{mg} / \mathrm{L}$; Chromium (Cr) of $0.23 \mathrm{mg} / \mathrm{L}$; and Lead $(\mathrm{Pb})$ of $0.33 \mathrm{mg} / \mathrm{L}$. Meanwhile in the Saguling Reservoir which is a reservoir to contain the water flow from the Citarum River itself has a concentration of $\mathrm{Cd}$ ranging from $0 \mathrm{mg} / \mathrm{L}-0.14$ $\mathrm{mg} / \mathrm{L}$ in water.

$\mathrm{Pb}, \mathrm{Cd}$ and $\mathrm{Cr}$ metals are the mostlikely-discovered metals in Saguling Reservoir in the last 2 years (data from Indonesia Power in
2016-2018). $\mathrm{Pb}$ and $\mathrm{Cd}$ metals are non-reactive metals in other words they are more stable than $\mathrm{Cr}$ metals which tend to react easily with any particular chemical compounds. The concentration of $\mathrm{Cd}$ and $\mathrm{Pb}$ metals can be found in water bodies, especially the Saguling Reservoir, which is an implication of the disposal of electroplating and workshop industrial waste to the Citarum River flow. Cd itself is a byproduct of $\mathrm{Pb}$ metal smelting process in the manufacture of electronic devices so that when talking about metals $\mathrm{Cd}$ is inseparable from the existence of $\mathrm{Pb}$ metal. Meanwhile, the concentration of $\mathrm{Cr}$ in water is generally caused by the disposal of textile industry's waste that enters the water stream. The existence of these metals in water is one of the biggest threats to human health because $\mathrm{Pb}, \mathrm{Cd}$ and $\mathrm{Cr}$ metals themselves have high levels of toxicity and can cause health problems when accumulated in the human body. Therefore, regular monitoring data is needed to monitor the level of concentration of heavy metals in water, especially $\mathrm{Cd}, \mathrm{Cr}$ and $\mathrm{Pb}$. However, there is not much time series heavy metal monitoring data that can be obtained, due to the high cost of heavy 
metal quality testing so that the characteristics and movements of the concentration cannot be determined.

To identify and determine the concentrations of $\mathrm{Pb}, \mathrm{Cd}$ and $\mathrm{Cr}$ in the Saguling Reservoir, a meticulous experimental approach can be a very exhasperating job especially when considering the possibility of environmental changes that occur due to fluctuations in flow of the river. Therefore, a numerical model can be used to predict metal concentrations such as $\mathrm{Cd}$, $\mathrm{Pb}$ and $\mathrm{Cr}$ contained in the Saguling Reservoir in a time series where calculations are based on the finite difference equation. In this study, simulation of heavy metal concentrations will be calculated using US EPA Water Quality Analysis and Simulation Program (WASP) software.

\section{Material and methods 2.1 Sample extraction}

This research was carried out in the water body of the Saguling Reservoir located in Saguling District, West Bandung Regency with coordinates $6^{\circ} 54^{\prime} 45$ "S and $107^{\circ} 21^{\prime} 58^{\prime \prime}$ E. Determination of sampling points in each of these zones also refers to the Indonesian National
Standard (SNI) 6989.57: 2008 concerning Water and Wastewater-Section 57: Methods for Collecting Surface Water Samples. Based on the SNI, taking water samples in the Saguling Reservoir was done by Grab Sampling at three depths with the aim of obtaining an overview of heavy metal concentrations on the surface, middle (1/2 depth) and bottom. Data on the results of testing of heavy metals will be used to conduct calibration and verification of the results of model simulations.

\subsection{Model segment determination}

Segmentation is one of the essential parts in making 1-dimensional models. Segment division will make it easier for researchers to understand the conditions in the field in each segment and make a formulation of boundary conditions in accordance to the morphology of each segment. Before entering into the WASP input, the geometry data in the Saguling Reservoir was divided into 9 (nine) segments according to the point of primary data sampling. Segment division can be seen in Figure 1.

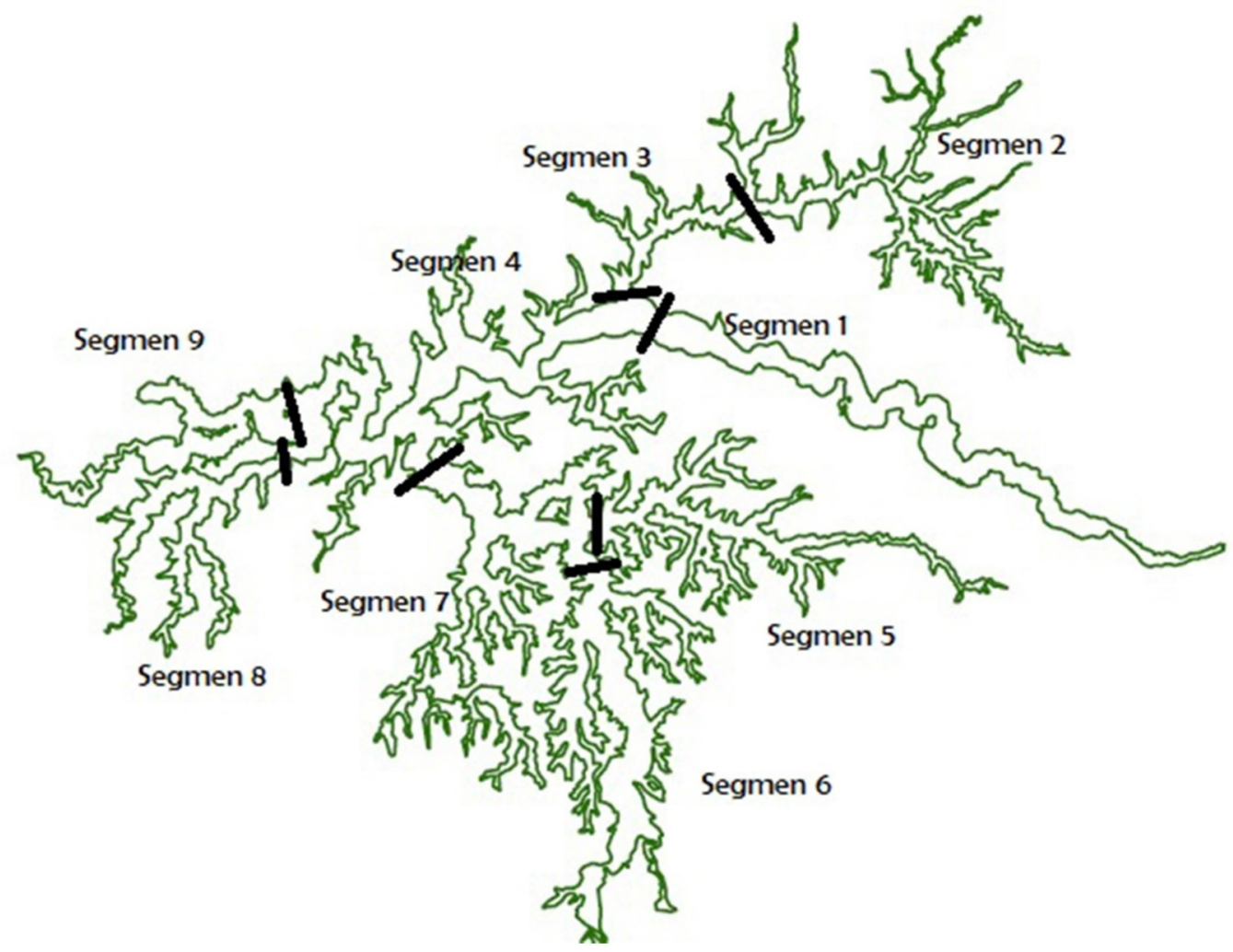

Figure 1. Saguling Reservoir model segmentation 
Segmentation was made based on the primary data sampling point by considering the characteristics and existing condition of each sampling point area. For example, in the area

around the sampling point 2 , starting from the boundary upstream to the downstream segment, there was a residential area that is also adjacent to an industrial area that has the potential to dispose of its wastewater into the Saguling Reservoir so that a segment with boundaries is included.

\subsection{Data input}

In this study, the input flowrate of the Saguling Reservoir was obtained from the data from the Citarum River Basin Central Data with the year of 2015 which provided debit flow data in units of days in one year. Due to the limitations and scarcities of the flowrate discharge data in time-series format from secondary data collection, this debit data was reused in the discharge simulation in 2018 which also became a debit for the basis of calculating heavy metal pollutant transport in the Saguling Reservoir. The use of this discharge was based on the assumption that there is no significant change in discharge from 2015 to 2018. The water flow in the Saguling Reservoir was assumed to be unsteady state flow or unstable flow due to variable changes such as heavy metal concentration over time.

In the reservoir morphology input, several columns related to reservoir geometry such as reservoir area, reservoir distance, minimum depth, volume need to be taken into account. In addition, the Manning roughness coefficient and slope of the channel also need to be considered because in the simulation model using WASP, the Manning's Open Channel Equation is an equation that will used in advective flow calculation if using the flow option 3 . The hydrodynamic phenomenon of this study was also calculated with flow 3 option using kinematic wave flow. The Manning roughness coefficient is assumed to be 0.04 which is a number used for natural bottom bed (soil) and the slope of the channel is assumed to be very small.The depth of the reservoir was not a specific consideration in this study because the output of the simulation is a 1-dimensional model in which each variable is only calculated on the $\mathrm{x}$ axis or longitudinal direction. Table of input data can be seen in Table 1.
Table 1. Saguling Reservoir Hidromorphology

\begin{tabular}{|c|c|c|c|c|}
\hline Segt. & Area $\left.\mathbf{( m}^{\mathbf{2}}\right)$ & $\begin{array}{c}\text { Volume } \\
\left.\mathbf{( m}^{\mathbf{3}}\right)\end{array}$ & $\begin{array}{l}\text { Manning } \\
\text { Coefficient }\end{array}$ & Slope \\
\hline 1 & 7562765 & 75627650 & 0.04 & 0.0001 \\
\hline 2 & 4636079 & 46360790 & 0.04 & 0.0001 \\
\hline 3 & 1579893 & 15798930 & 0.04 & 0.0001 \\
\hline 4 & 6643936 & 66439360 & 0.04 & 0.0001 \\
\hline 5 & 5801860 & 58018600 & 0.04 & 0.0001 \\
\hline 6 & 4997683 & 49976830 & 0.04 & 0.0001 \\
\hline 7 & 4810759 & 48107590 & 0.04 & 0.0001 \\
\hline 8 & 3752429 & 37524290 & 0.04 & 0.0001 \\
\hline 9 & 4635497 & 46354970 & 0.04 & 0.0001 \\
\hline
\end{tabular}

Some coefficients that affect the transport of heavy metals in both water and sediments in the Saguling Reservoir such as the values of heavy metal density, precipitation rate, advective factor, and dispersion coefficient. Heavy metal density is one of the coefficients that can be used as a reference to determine the ability to settle for a particular metal. However, there are still a number of external factors that influence the deposition of heavy metals in water bodies such as the presence of heavy metal adsorption on the surface of particles of suspended solids, erosion, binding to certain compounds so that accumulation occurs and then forming particles large enough to settle.

Data from external factors are difficult to obtain and also difficult to predict so that in this study, these factors can be ignored. In addition to the coefficients mentioned above, one of the coefficients that need to be included in the model formulation is metal partition coefficient $\mathrm{Cr}, \mathrm{Cd}$, and $\mathrm{Pb}$. and $\mathrm{Pb}$ is distributed in two phases namely solid and liquid in this case related to the deposition process. The list of coefficients can be seen in Table 2.

Settling velocity are mostly determined by particles density and size, however, heavy metals could not perform a perfect sedimentation unless there are several suspended solids that allowed them to settle on the surface of those particles. It was assumed that the heavy metals (both ionic and other forms) would settle in particle with settling velocity about $0,1 \mathrm{~m} /$ day according to the previous study in Saguling Reservoir. In this study, the dispersion rate for each heavy metals were determined based on the ionic form of the heavy metals. Mass transfer of each heavy metals in water is influenced by several factor such as ionic radius, presence of other type of ions, ionic charge, coefficient of determination, etc. All of those factors are incorporated into effective dispersion coefficient. The research to determine dispersion coefficient are not included in this study due to out of boundaries and scope of research. 
Table 2. List of coefficient for heavy metals input

\begin{tabular}{|c|c|c|}
\hline Characteristics & Value & Engineering \\
\hline Cadmium density & $8640 \mathrm{~kg} / \mathrm{m}^{3}$ & $\begin{array}{c}\text { Engineering } \\
\text { Toolbox (2004) }\end{array}$ \\
\hline Chromium density & $7190 \mathrm{~kg} / \mathrm{m}^{3}$ & $\begin{array}{c}\text { Engineering } \\
\text { Toolbox (2004) }\end{array}$ \\
\hline Lead density & $11400 \mathrm{~kg} / \mathrm{m}^{3}$ & $\begin{array}{c}\text { Engineering } \\
\text { Toolbox (2004) }\end{array}$ \\
\hline Settling velocity & $0.1 \mathrm{~m} /$ day & Panelin (2013) \\
\hline Sedimentation rate & $\begin{array}{c}4.2 \text { million } \\
\mathrm{m}^{3} / \text { year }\end{array}$ & Panelin (2013) \\
\hline \multirow[t]{3}{*}{ Dispersion rate } & $0.1 \mathrm{~m}^{2} / \mathrm{second}$ & $\begin{array}{l}\text { Stevens dkk. } \\
\text { (2004) }\end{array}$ \\
\hline & $1 \mathrm{~m}^{2} /$ second & $\begin{array}{l}\text { Pintillie dkk. } \\
\text { (2007) }\end{array}$ \\
\hline & $2.5 \mathrm{~m}^{2} / \mathrm{second}$ & $\begin{array}{l}\text { Anastasiani } \\
\text { dkk. (2007) }\end{array}$ \\
\hline $\begin{array}{l}\text { Partitioncoefficient } \\
\qquad \mathrm{Cr}\left(\log \mathrm{K}_{\mathrm{D}}\right)\end{array}$ & $4.5 \mathrm{~L} / \mathrm{kg}$ & $\begin{array}{c}\text { Allison dan } \\
\text { Allison (2005) }\end{array}$ \\
\hline $\begin{array}{l}\text { Partitioncoefficient } \\
\qquad \mathrm{Cd}\left(\log \mathrm{K}_{\mathrm{D}}\right)\end{array}$ & $3.6 \mathrm{~L} / \mathrm{kg}$ & $\begin{array}{c}\text { Allison dan } \\
\text { Allison (2005) }\end{array}$ \\
\hline $\begin{array}{l}\text { Partitioncoefficient } \\
\qquad \mathrm{Pb}\left(\log \mathrm{K}_{\mathrm{D}}\right)\end{array}$ & $5.1 \mathrm{~L} / \mathrm{kg}$ & $\begin{array}{c}\text { Allison dan } \\
\text { Allison (2005) }\end{array}$ \\
\hline
\end{tabular}

Meanwhile for pollutant load input is done by using data from preliminary studies in 2018 and data from the testing results of the Indonesia Power field in 2018 which is calculated based on point 1 which is the main input of pollutant load from the main stream of Saguling Reservoir originating from the Citarum River. The results of pollutant load calculations can be seen in Table 3.

Table 3. Waste load calculation results for

\section{$\mathrm{Cd}, \mathrm{Pb}$ dan $\mathrm{Cr}$}

\begin{tabular}{|l|r|r|l|r|}
\hline Metal & $\begin{array}{l}\text { Flowrate } \\
\text { (m3/day) }\end{array}$ & $\begin{array}{l}\text { Concentra } \\
\text { tion } \\
\text { (gr/m3) }\end{array}$ & $\begin{array}{l}\text { Concent } \\
\text { ration } \\
\text { (kg/m3) }\end{array}$ & $\begin{array}{l}\text { Loading } \\
\text { (kg/day) }\end{array}$ \\
\hline $\mathbf{C d}$ & 5356800 & 0.01185 & 0.00001 & 63.478 \\
\hline $\mathbf{P b}$ & 5356800 & 0.1169 & 0.00011 & 626.202 \\
\hline $\mathbf{C r}$ & 5356800 & 0.00832 & 0.00000 & 44.568 \\
& & & 832 & \\
\hline
\end{tabular}

\subsection{Modelling using WASP}

For the 1-Dimensional model, the model only considers longitudinal dispersion (x-axis). Vertical and lateral pollutant transport is assumed to be homogeneous because in the 1-dimensional model, the movements of variables such as concentration, flow rate, flow velocity and so on are only calculated from one direction, namely the $x$ axis only. The finite difference equation used by WASP to calculate concentrations in changes in space and time is as follows:

$$
\begin{aligned}
& \frac{\partial}{\partial t}(A C)=\frac{\partial}{\partial x}\left(-U_{x} A C+E_{x} A \frac{\partial C}{\partial x}\right)+A\left(S_{L}\right. \\
& \left.+S_{B}\right)+A s k+A S_{K}
\end{aligned}
$$

where,

$\mathrm{C}=$ concentration $(\mathrm{mg} / \mathrm{L})$ atau $\mathrm{gr} / \mathrm{m}^{3}$

$\mathrm{t}=$ time, day

$\mathrm{U}_{\mathrm{x}}=$ longitudnal advection velocity, $\mathrm{m} /$ day

$\mathrm{E}_{\mathrm{x}}=$ longitudinal dispersion coefficient, $\mathrm{m}^{2} /$ day

$\mathrm{S}_{\mathrm{L}}=$ direct/diffuse waste load, $\mathrm{g} / \mathrm{m}^{3}$-day

$\mathrm{S}_{\mathrm{B}}=$ boundary waste load, $\mathrm{g} / \mathrm{m}^{3}$-day

$\mathrm{S}_{\mathrm{k}}=$ total kinetic transformation, $\mathrm{g} / \mathrm{m}^{3}$-day

The equation includes pollutant transport processes that occur in the body of water to the concentration of pollutants such as the transport process (term 1) and the loading process (term 2) and kinetic processes (term 3). To calculate an advective flow in a reservoir, hydraulic calculations for open channels (Manning Equations) are used as follows:

$$
Q=\frac{1}{n} \times \frac{A^{5 / 3}}{B^{2 / 3}} \times S^{1 / 2}
$$

\subsection{Simulation and calibration}

The simulation process using WASP is divided into three stages namely pre-processing, processing and post-processing. Along preprocessing step, coefficient and the other input variable were defined and prepared. Then, the geometry data input including the initial conditions and modelling boundary were adjusted based on geospatial observation of the segments that acquired through Google Earth. Input flow direction and connection from each segment is also needed to specify the flow distribution and concentration of heavy metals. After the model is simulated, the calibration process is carried out in the post-processing step by comparing the output of the model with the available data. Then a statistical analysis was performed using Root Mean Square Error (RMSE) and Relative Error (RE). 


\section{Results and Disscusion}

\subsection{Simulation results of Cadmium, Lead and Chromium concentration in water}

The simulation results of Cadmium Lead and Chromium can be seen in Figure 2. Some hydraulic parameters such as depth, pressure, density are assumed to be constant which changes only the incoming discharge. Cadmium and Lead simulations in this paper are represented by only in Segment 1 while the Chromium concentration represented by Segment 2 is done because of historical data, Chromium in segment 1 is not detected, therefore upstream boundary concentration for segment 1 is $0 \mathrm{mg} / \mathrm{L}$. From the overall simulation results, it can be seen that there was an increase in June to the beginning of October which was a representation of the dry season while there was a significant decline at the end of October to December which is a representation of the wet season.

Seen in the Figure 2, the red line shows the quality standard of the metal concentration required by PP No.82 of 2001 for class II rivers. The metal quality standards of Cadmium, Lead and Chromium are respectively $0.01 \mathrm{mg} / \mathrm{L} ; 0.03$ $\mathrm{mg} \mathrm{/} \mathrm{L} \mathrm{and} 0.05 \mathrm{mg} / \mathrm{L}$. In the metal concentration model, the Chromium metal concentration model is the only one that meets the quality standards of concentration in class II rivers. The model of Cadmium, Chromium, and Lead metal concentration in Figure 2 provides an overview of how the behavior / behavior of these metals in the waters of the Saguling Reservoir in the dry and wet season so that it can be an early warning for the management of the reservoir and the agency responsible for the management of the Saguling Reservoir in order to give full attention to the management of reservoirs in these seasons.

From the model it can be seen that the possibility of increasing the concentration of the metal in question in the dry season is very large and certainly will be many times greater than that which occurs in the wet season where the metal concentrations of Cadmium, Chromium and Lead tend to decrease. The decrease in concentration in the wet season often results from a dispersion function in the transport of heavy metal pollutants which makes heavy metals more easily spread from one point to another so that it is not concentrated at one point.

From some literature and monitoring data in 2016-2018, testing of heavy metals especially for water testing is more often done in October-November-December which is actually a wet season so often heavy metal concentrations are found to be nil or below the detection limit. This is because in the wet season, there is dispersion and dilution of pollutants so that the detected data is quite low.

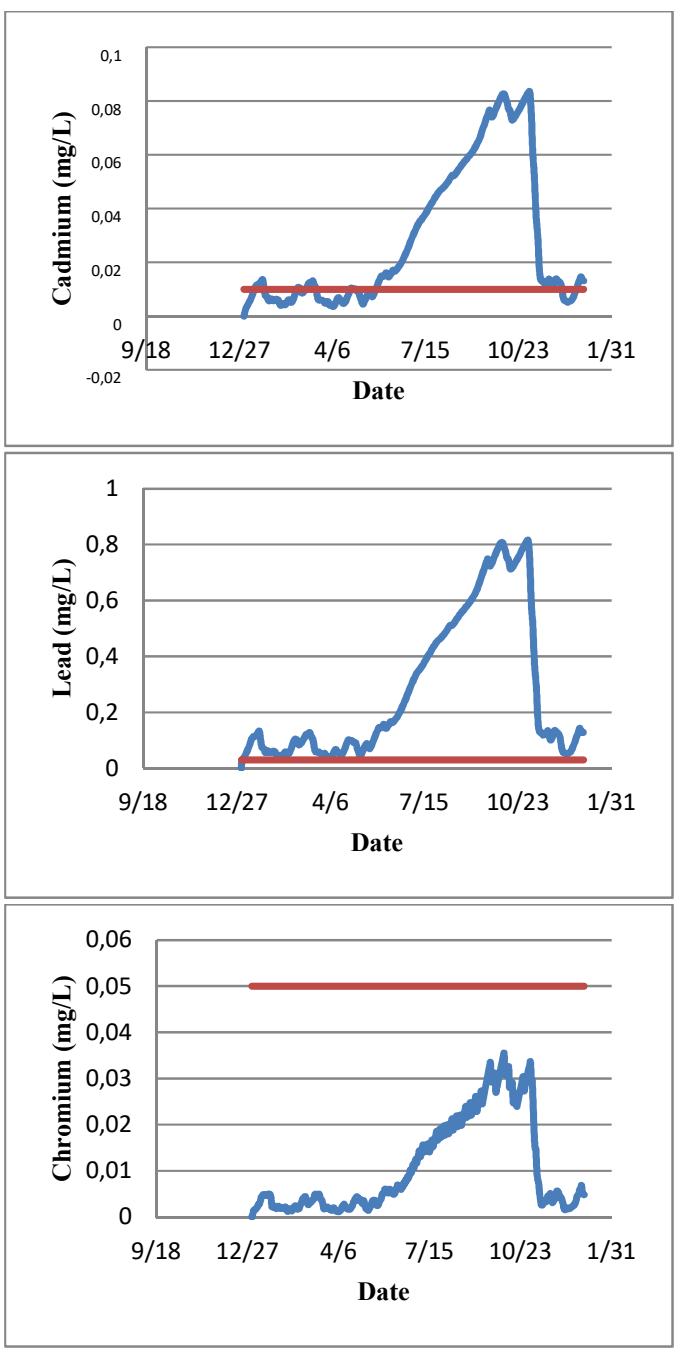

Figure 2. Cadmium, Lead and Chromium concentration

Therefore, testing should also be carried out in June-July-August which is a representation of the dry season.

\subsection{Cadmium, Lead and Chromium simulation results in sediment}

Simulation results of cadmium, lead and chromium in sediments can be seen in Figure 3. From the picture, it can be seen as time running in each day, considering that the input of heavy metal loads and settling speed is constant, then the concentration of heavy metals in the sediment will continue to increase and continue to accumulate in the sediment column. 


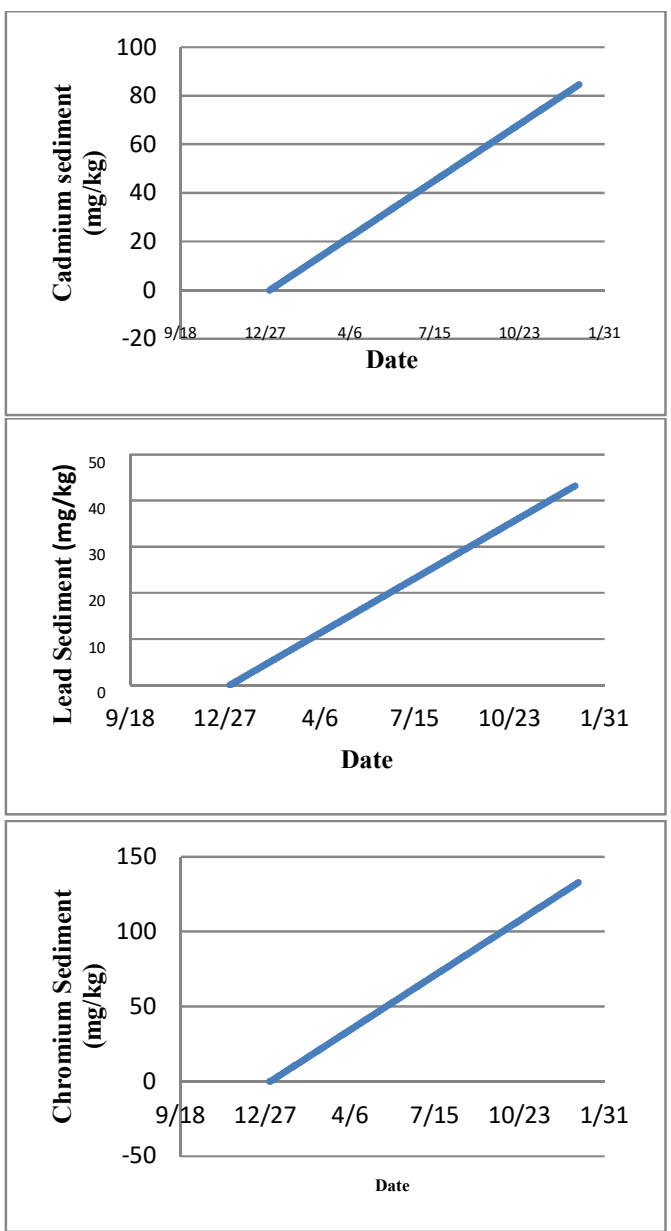

Figure 3. Cadmium, Lead and Chromium concentration in sediment

Modelling Cadmium, Lead and Chromium concentration in sediment uses an assumed density of $8670 \mathrm{~kg} / \mathrm{m}^{3}, 11400 \mathrm{~kg} / \mathrm{m}^{3}$, $7650 \mathrm{~kg} / \mathrm{m}^{3} \quad$ respectively (Engineering Toolbox,2004), a settling speed of $0.1 \mathrm{~m} /$ day and the dissolved fraction is 0 assuming that all dissolved metals will undergo a complete precipitation and accumulate from time after time. This sediment model is made by ignoring variations of the dry season and rainy season so that there is no fluctuation in the concentration of those metals in the sediment. According to Chiba et al. (2011), the concentration of heavy metals in sediments cannot be used as a measurement to interpret the influences of seasonal variations on the concentration of heavy metals in water bodies. Henceforth, there are many factors that influence the occurrence of sedimentation such as the physical condition of water bodies, adsorption, desorption, temperature, $\mathrm{pH}$, aquatic biota, erosion and other external factors.

This assumption is also made based on the scope of research that does not consider bioaccumulation which could possibly occur in marine biota due to uptake of the metal. These assumptions cause the calculated cadmium, lead and chromium concentration in the model to have an ever-increasing concentration value.

From another study, similar model results were also obtained by Pintillie et al. (2007) where the simulation of cadmium models in sediments showed a constant increase from the first day of the simulation to the last day of the 250th day.

\subsection{Cadmium, Lead and Chromium in water model calibration and verification}

Calibration and verification is done by comparing the results of the models in each segment with the actual data from observations in the field. Calibration and verification are only carried out based on each segment data and do not take into account time changes due to the difficulty of obtaining heavy metal data in the time series format. Calibration is done to determine whether the dispersion coefficient is in accordance with natural conditions, while verification is carried out to determine how close the output of the simulation model is to the actual data. The dispersion coefficient in the model must be chosen specifically through literature studies or laboratory research results.

The dispersion coefficient will be different from the context of the research conducted whether the coefficient is assumed to be a molecular movement or longitudinal flow in rivers or water bodies. The model is made based on variations in the dispersion coefficient and then the errors that occur in the modeling process are calculated using the statistical approach. In this study used Root Mean Square Error and Relative Error. Calibration of the results of the model in this study used a variation of the dispersion rate coefficient with a number of 0.1 $\mathrm{m}^{2} /$ second; $1 \mathrm{~m}^{2} /$ second (Pintillie et al., 2007); $2.5 \mathrm{~m}^{2} /$ second (Anastasiani et al., 2007). The results of calculations with variations in the value of the dispersion coefficient can be seen in Table 4 and Table 5.

Table 4 RMSE calculation summary

\begin{tabular}{|l|r|r|r|}
\hline \multirow{2}{*}{ Parameter } & \multicolumn{3}{|c|}{ RMSE } \\
\cline { 2 - 4 } & $\begin{array}{c}\mathbf{0 . 1} \\
\mathbf{m}^{2} / \mathbf{s e c o n d}\end{array}$ & $\begin{array}{c}\mathbf{1} \\
\mathbf{m}^{2} / \mathbf{s e c o n d}\end{array}$ & $\begin{array}{c}\mathbf{2 . 5} \\
\mathbf{m}^{2} / \mathbf{s e c o n d}\end{array}$ \\
\hline $\begin{array}{l}\text { Cadmium } \\
(\mathrm{Cd})\end{array}$ & 0.005153 & 0.005150 & 0.005638 \\
\hline Lead $(\mathrm{Pb})$ & 0.028215 & 0.028211 & 0.028205 \\
\hline $\begin{array}{l}\text { Chromium } \\
(\mathrm{Cr})\end{array}$ & 0.005951 & 0.005951 & 0.005953 \\
\hline
\end{tabular}


Tabel 5 RE calculaton summary

\begin{tabular}{|l|r|r|r|}
\hline \multirow{2}{*}{ Parameter } & \multicolumn{3}{|c|}{$\mathbf{R E}$} \\
\cline { 2 - 4 } & $\begin{array}{c}\mathbf{0 . 1} \\
\mathbf{m}^{2} / \mathbf{s e c o n d}\end{array}$ & $\begin{array}{c}\mathbf{1} \\
\mathbf{m}^{2} / \mathbf{s e c o n d}\end{array}$ & $\begin{array}{c}\mathbf{2 . 5} \\
\mathbf{m}^{2} / \mathbf{s e c o n d}\end{array}$ \\
\hline $\begin{array}{l}\text { Cadmium } \\
(\mathrm{Cd})\end{array}$ & 0.34099 & 0.34077 & 0.37063 \\
\hline Lead(Pb) & 0.412797 & 0.412691 & 0.412516 \\
\hline $\begin{array}{l}\text { Chromium } \\
(\mathrm{Cr})\end{array}$ & 0.26626 & 0.2847 & 0.3383 \\
\hline
\end{tabular}

From the results of Table 4 it can be seen that the value of the smallest relative error for each of the Cadmium, Chromium, and Lead metals sequentially is in the model with a dispersion coefficient of $1 \mathrm{~m}^{2} /$ second (with a relative error of $34.077 \%$ ); $0.1 \mathrm{~m}^{2} /$ second (with a $26 \%$ relative error); and $2.5 \mathrm{~m}^{2} /$ second (with a $41.25 \%$ relative error). From the value of the coefficient it is obtained that the value of the relative error is quite large, which is above $30 \%$, due to the lack of data and the lack of input parameters that have the potential to affect the concentration of heavy metals in water.

In the verification phase, secondary data from the research results obtained from several journals with a year range of 2015-2018 and water quality testing data from Indonesia Power in 2018. Verification is done after obtaining the dispersion rate coefficient from the calibration stage, ie dispersion rate in $\mathrm{Cd}$ metal, $\mathrm{Cr}$ and $\mathrm{Pb}$ of $1 \mathrm{~m}^{2} /$ second; $0.1 \mathrm{~m}^{2} /$ second; and $2.5 \mathrm{~m}^{2} /$ second. The graph of verification results using the relative error for the Cadmium, Lead and Chromium metal models can be seen in Figure 4.

Differences in model data and observations in several segments are the cause of the magnitude of the error produced. An error can occur due to a mismatch between the assumptions used and the formulation of the model for the actual natural conditions in the field. Making a model that is close to natural conditions is very difficult and the ideal conditions used in the model assumptions often do not occur in the field.

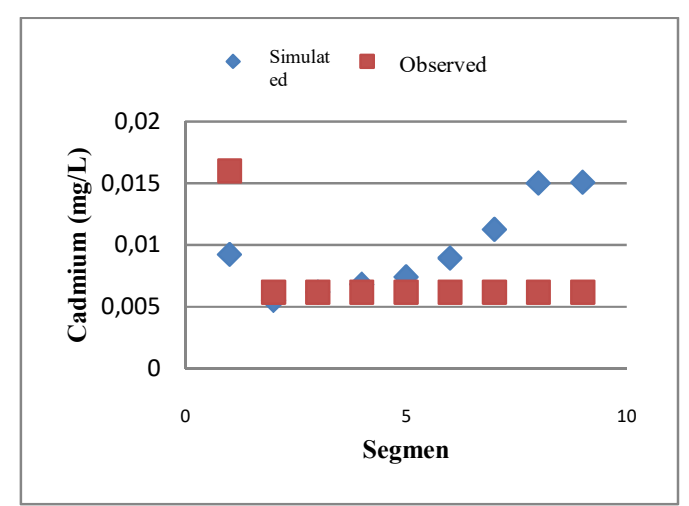

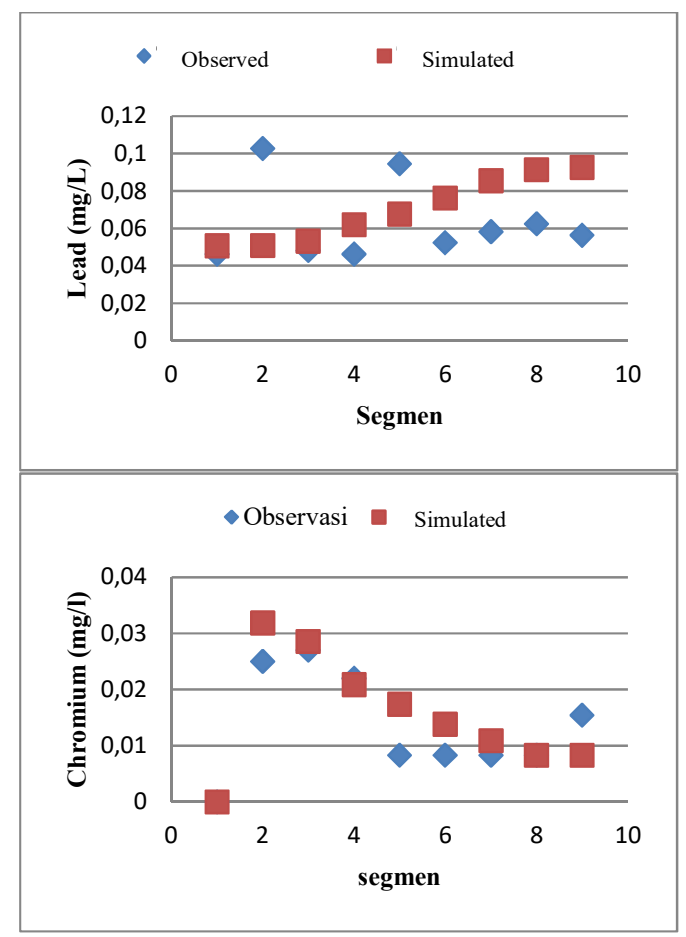

Figure 4. Cadmium, Lead, and Chromium in water Calibration and Verification (continued)

Besides that, environmental quality data is generally not normally distributed, possesses arbitrary and random properties, so it is difficult to predict the natural conditions of water bodies with numerical models. Another cause of error is coefficient data taken from foreign sources such as partition coefficients and dispersion coefficients taken from foreign literature. Environmental conditions outside Indonesia are of course different from those in Indonesia which in fact is a tropical country. However, domestic literature which contains research on these coefficients is still minimal, so it must be taken from literature from abroad. Other causes of errors can also occur in the process of retrieving observational data itself such as errors in sampling, errors in conditioning samples and errors in conducting laboratory tests that cause data to be random and not normally distributed.

\subsection{Cadmium, Lead and Chromium in sediment model verification}

The relationship between cadmium concentrations in sediments, both simulation results and field observations can be seen in Figure 5. In the picture, it is observed that the output of the model has a considerable degree of correlation when compared with observational data in the field. The data used for verification is from Wardhani (2016). From the results of statistical analysis using RMSE, an error value of 18.53 was obtained while for the RE value it was obtained at 0.77 or it could be said to occur at 
$77 \%$ error when performing calculations (approximation).

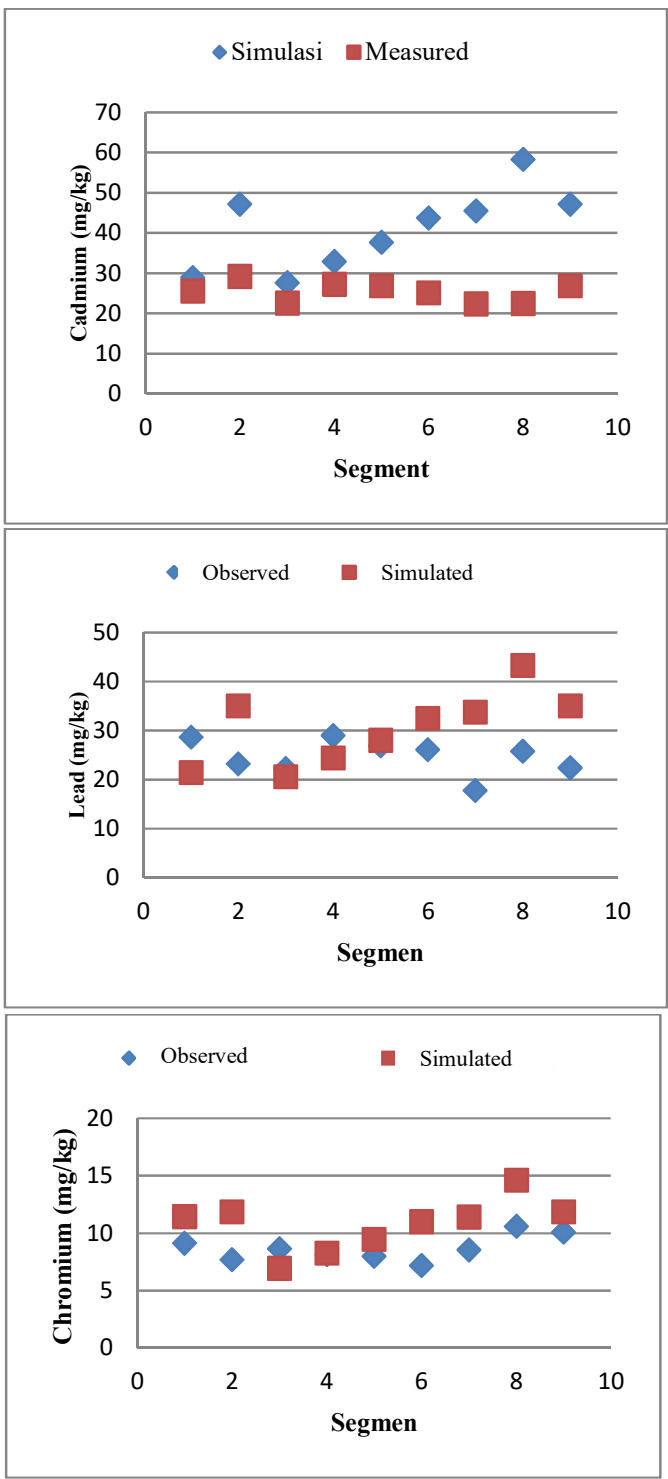

Figure 5. Cadmium, Lead dan Chromium on sediment model verification

While for the concentration of Lead metal in sediments, the results of statistical analysis using RMSE, obtained an error value of 10.43 while for the $\mathrm{RE}$ value obtained at 0.4715 or it can be said to occur at $47.15 \%$ error when performing calculations (approximation). The lowest error was obtained by the Chromium metal model in sediments, obtained an error value of 2.789 while for the RE value obtained at 0.333 or it could be said to occur at $33 \%$ error. This large error arises because the input parameters when the model formulation is limited to the availability of data and literature. In addition to parameters such as erosion factors and dissolved solids, other parameters or constants such as dissolution parameters are not included in the WASP model because there are no input options for these constants and also some constant data are not available for certain heavy metals.

\section{Conclusion}

This study uses the Water Analysis and Simulation Program (WASP) software to simulate the concentration of heavy metals in the Saguling Reservoir in the form of a 1-Dimensional model. Heavy metal which is the simulation object in this research is Cadmium. From the results of the model calibration test using the Root Mean Square Error (RMSE) analysis and Relative Error (RE) analysis, obtained dispersion coefficients on Cadmium, Chromium, and Lead metals sequentially $1 \mathrm{~m}^{2} /$ second (with RMSE 0.00515 and relative error $34 \%$ ); $0.1 \mathrm{~m}^{2} /$ second (with RMSE 0.0059 and relative error $28 \%$ ); and 2.5 $\mathrm{m}^{2} /$ second (with RMSE 0.028205 and $41.25 \%$ relative error). From the model results, it can be concluded that there is a surge in the concentration of heavy metals Cadmium, Chromium and Lead in the body of the water when the discharge is in a minimum condition and there is a decrease in concentration when the discharge is in the maximum condition.

From the results of the verification test models of concentration of cadmium, lead and chromium in sediments using the Root Mean Square Error (RMSE) analysis and Relative Error (RE) analysis, obtained sequentially 18.53 and $77 \% ; 10.43$ and $47.15 \% ; 2,789$ and $33 \%$.

\section{Acknowledgement}

On this occasion the author would like to address a special thanks to U.S. EPA who was a legitimate developer of WASP modeling software. Author also deliberately appreciate to every staff efforts in Balai Lingkungan Pertanian (Balingtan) located in Jakenan, Pati that has provided heavy metal testing services to the author.

\section{Reference}

1. J.D. Allison and T. L. Allison. U.S. EPA, Athens, GA. EPA/600/R-05-074 (2005)

2. S. Anastasiani, Master's Thesis of Env. Eng., (Institut Teknologi Bandung, 2007)

3. W.A.C. Chiba, M.D. Passerini, J.A.F. Baio, J.C. Torres, J.G. Tundisi, São Carlos Brazilian J. Bio. vol. 71 no.4 (2011)

4. Desiana, Prilia, Oginawati, Katdayna, dan Ariesyady, Herto Dwi. (2013). J. Wat. Sus, Vol. 3, Issue 2, University of Technology Sydney dan Xi' an University of Architecture and Technology, pp.107-116. 
5. Engineering Toolbox (2004) $<$ https://www.engineeringtoolbox.com/metalalloys-densities-d_50.html>, accessed: March 23th 2019

6. Indonesia Power, PT. Indonesia Power UBP Waduk Saguling (2018).

7. Y. Panelin, Master's Thesis of Env.Eng. (Institut Teknologi Bandung, 2013)

8. S. Pintillie, L. Branza, C. Betianu, L. Vasile Pavel, F. Ungureanu, and M. Gavrilescu, J. Env. Eng. Mgmt. Vol. 5 No.2, pp. 153-101.
Gh. Asachi Tech. Univ. of Iasi, Romania. (2007).

9. Republik Indonesia, PP. No. 82/2001.

10. C. L. Stevens., G.A. Lawrence, and P.F. Hamblin, J. Env. Eng. and Sci., 2004, 3(5) : 413-417 (2004).

11. E. Wardhani, D. Roosmini, dan $\mathrm{S}$. Notodarmojo,Jurnal Manusia dan Lingkungan Vol. 23, No.3 pp. 285-294. (2016). 